\title{
Research and Practice on the Construction of Teaching Practice Base of Agricultural Engineering Discipline
}

\author{
Hongying Sun ${ }^{1}$ \\ College of Engineering and Technology, Tianjin \\ Agricultural University, Tianjin, 300384, China
}

\author{
Guimei Dong, Renjie Yang,Yong Wei \\ College of Engineering and Technology, Tianjin \\ Agricultural University, Tianjin, 300384, China
}

\begin{abstract}
Teaching practice base is an important basis for school and enterprise cooperation. Its construction is directly related to the teaching quality of the internship, which has a special effect on cultivating students' innovative spirit and practical ability. This paper proposes an innovative solution through comparative analysis. On the basis of traditional practice, we should strengthen the construction of teaching practice base on campus and improve the construction of teaching practice base on campus. At the same time, sufficient experimental teaching equipment should be provided to enable students to understand the basic situation of production before the internship. Finally, improve students' comprehensive quality.
\end{abstract}

Keywords-Teaching practice base; Construction; Practice

\section{THE IMPORTANCE OF TEACHING PRACTICE}

\section{A. Teaching practice is the key to strengthen students'} comprehensive application ability.

The teaching practice of agricultural engineering discipline requires students to comprehensively apply the professional knowledge, such as the principles of automobile tractor, mechanical design, agricultural machinery, agricultural products processing machinery, etc. For example, in an internship, if there is a failure of the corn no-till planter, the instructor and the student union will work together to find out the cause of the failure, and then propose solutions and implementation methods. In the process, the students' practical ability can be clearly reflected, and requires the students to be bold and careful, and not afraid of dirty, not afraid of tiredness.

In practice, the user generally reflect the tractor can't keep up with foreign and domestic not make not only, and not make resistance, high failure rate, use a single, high maintenance cost, this will give student of mechanical design raises new questions. Machine not durable in part because of the unqualified material, mostly because of the design and manufacturing technology level, the designer should not only consider the purposes, more should think of what kind of shape with existing domestic manufacturing process can meet the requirements of manufacturing, durable; Another reason for poor durability is improper use, some mechanical poor ability to overcome obstacles in the process of marching, once the user didn't notice, the original speed, under the effect of

\section{ACKNOWLEDGMENT:}

This work was financially supported by the Research Project of Quality of Teaching and Reform in Education of Undergraduate in Tianjin College (1 71006101C), and Tianjin Science and Technology Development Fund of H igher School (20140621). external force, the main pieces of vulnerable; Furthermore, agricultural machinery is often continuous operation, without timely finishing or maintenance, it is easy to cause fatigue damage. Therefore, this is a reminder to students to take into account the poor conditions of farm tools, enhance the ability to remove obstacles, and simplify operations.

\section{B. Teaching practice reflects the combination of practical ability and theoretical analysis.}

One is to use a schematic diagram to help memory. In the internship, students are arranged to understand the structure and function of various agricultural machinery and tools. The sketch can illustrate the relative position, working process and structure characteristics of each part. Secondly, with the "atlas" structure, can give a physical concept is not strong students bring great convenience, so that the students for physical to further make clear the structure of the book referred to in the physical, graphics and structure.

\section{The raising and discussion of new problems is an important part of teaching practice.}

Whether students can apply theory to practical thinking and whether they can grasp practical problems in teaching practice depends on whether they can raise new problems in practice. In the teaching practice, students are encouraged to compare the campus experiment and base internship to find the same and different places, and analyze the reasons.

\section{Teaching practice realizes the longitudinal coherence and} systematicness of the curriculum system.

Practical teaching and theoretical teaching have their own characteristics. Through teaching practice, practical teaching and theoretical teaching are equivalent in both content and form. In theoretical teaching, knowledge is mainly taught, with clear goals and requirements. Similarly, practice teaching in addition to help, to deepen understanding of course related theory and master outside, more important is to college students' basic skills, the cultivation of engineering practice ability and engineering consciousness.

In order to develop modern engineer should have the basic qualities, teaching, scientific research and social service should be organically, to let the students to participate in and accord with the actual situation of modern engineering environment 
through exercise, gradually cultivate the ability to solve practical engineering problems, and consciousness, enables students to society after the preliminary ability in engineering practice.

Practice teaching to achieve the combination of teaching, production and scientific research, cultivate the students' ability of independent working ability and professional strain, causes the student to understand the forefront of production and research status and development trends, to in-depth study on the practice [1].

The establishment of the practice base provides a broad space for student internship, which can basically meet the requirements of practical teaching. Practice base of good equipment and management system not only enriches the teaching content, and to enhance the students' learning enthusiasm, changed the past focus on classroom teaching, ignoring the status of the practice teaching link, so that students get the practice exercise, so that the students in the process of contact with the production practice, to further understand and familiar with the learning content and requirements of the professional, rigorous, realistic, disciplined, punctual attitude toward study and work, for the subsequent course of study and employment work has laid a solid foundation [2].

\section{THE MEANING OF TEACHING PRACTICE}

\section{A. Improve social practice ability}

It can let students early experience of life, feel the time pulse, to understand the characteristics of the social demand for talents, etc., so that to correct their own learning behavior, pay more attention to practical teaching activities, exercise capacity, inspection learning professional knowledge, and then consciously participation, exercise, improve their social practice ability.

\section{B. Cultivate self-reliance}

Off-campus base practice is an important link between students' understanding of the actual production situation and the comprehensive application of their knowledge, which is the bridge and link to the society. Through the internship, education students develop the spirit of hard work, hard work and hard work. In order to enhance students' self-confidence, cultivate self-reliance and help students to build up the sense of competition and benefit.

\section{Cultivating scientific research quality}

The practice base is beneficial to the development of project research, cultivating scientific research quality and obtaining scientific research results. In the course of teaching practice, the advantages and problems of the base are used to determine the research topic and the systematic observation and research. In this way, both well trained the scientific attitude and quality of teachers and students, improve the ability of scientific research, and for students in schools for the extra-curricular science and technology activities, and after the graduation engaged in scientific research laid a good foundation.

\section{Teaching practice promotes teacher education and improves teacher quality.}

Work practice teaching is an important part of school teaching work, set up a group of high levels of practice base and the stability of a high quality of practice guidance teachers is the essential guarantee of the school construction and development.

Instruct teachers to be responsible for the whole process of student internship, to get a thorough understanding of the students' thoughts, and to care about their internship, life and other conditions. Wants to coordinate the relationship between the school and internship units and students trying to solve the problems and difficulties in practice, urge the students to strictly abide by the internship units and college's rules and regulations, guiding the students completed an internship. In this process, teachers keep on learning, renewal education idea, renewing knowledge, active exploration and practice of agricultural the new methods of higher education, broaden knowledge, record of formal schooling and professional skills.

\section{THE METHOD AND EFFECT OF INNOVATION TEACHING PRACTICE BASE CONSTRUCTION}

\section{A. Establishing organization and division of responsibilities.}

Establish teaching practice base construction leading organization, overall planning, rational layout, unified management. Responsible for the planning and basic documents of the construction of teaching practice base, review and determine the layout of teaching practice base, check and evaluate the teaching practice quality and other work.

\section{B. Improving the system and improve management.}

According to the needs of teaching practice, we should gradually establish and improve the management system of teaching practice base construction and teaching practice, and the school and the internship unit regularly contact the system and make rules and regulations. By establishing and perfecting various rules and regulations, the healthy development of teaching practice base and the steady improvement of teaching practice quality are guaranteed.

\section{Increasing the cost of teaching and training.}

Lodging expenses of teaching is the important guarantee of teaching practice activities can go smoothly, on the one hand, in a second school actively advocate economical use of practice teaching funds at the same time, on the other hand many raise money, practice teaching funds investment increasing year by year, and according to the scale of students and discipline characteristic, the reform practice teaching funds allocation method, make a practice teaching cost allocation more reasonable, the use of more formal.

\section{Expanding cooperation areas and deepen cooperation.}

Through the signing of the agreement and the way to issue the plaque of the internship base, the relationship of long-term cooperation in the form and content will be clearly defined, and the sense of honor and sense of responsibility of the agreement unit will be enhanced from the thought.

Practice teaching base is the cooperation between colleges and the importance of combining production, study and 
research basis, let the student fully absorbs the nutrition of enterprise culture, capture market information, understand the latest production technology, study the production management idea; It also strengthens students' theoretical knowledge, trains students' practical ability, innovation ability and dedication, entrepreneurial spirit, broadens students' vision, strengthens the concept of labor, and deepens students' professional skills. And it plays an important role in the construction of high quality teachers, which is beneficial to the development of teachers' scientific research activities.

Graduation design is the last part of undergraduate teaching, and also an important way to conduct scientific research training for undergraduates. Based on the professional training objectives, the teaching practice base combines the research projects with the basic theory and engineering practice as the students' graduation design topic. The result of the survey shows that whether it is the students' enthusiasm or the final quality of the thesis, the subject matter of the engineering background is better than the topic without the engineering background.

\section{EXISTING PROBLEMS AND COUNTERMEASURES}

Although some achievements have been made in the construction and management of teaching practice base, the problems still exist in many aspects, mainly in the following aspects

\section{A. Insufficient understanding}

Internship unit. Most of these units do not have internship conditions, unable to carry out graduation thesis or graduation design. The requirements for student management are not strict. Students are looking for the internship units, mainly due to their inadequate knowledge of the purpose and importance of practice, don't realize this is a good chance to contact society, theory with practice, especially for those who do not intend to students engaged in this professional work after graduation, they think the internship is not helpful for future work, learn and not learn the same, so hope internship units to stay close to home, some management loose, they can complete the task, moreover just find a unit front, I was less than unit internship.[3]

\section{B. Lack of attention}

Individual students have not attached great importance to the teaching practice, failing to strictly abide by the relevant regulations of the interns, and went out to find work without asking for leave, which caused a bad influence. And some students even though in practice very hard, enthusiasm high, want to learn more knowledge, mastering skills, but because of the knowledge base, practice condition and so on various aspects reason, makes them feel unsatisfied with, influence the practice effect.

\section{The lack of guidance}

In the process of practice, practice base for most of the leadership attaches great importance to and support the student internship, project, plan, guide, summary and recognition, but also some less than done, for example, is not enough, to the student internship identification is not very seriously, and simple comments too.

\section{Adhere to the principle of two hand holding in the teaching practice base}

At the same time of strengthening the construction of offcampus practice teaching base, be sure to intensify campus practice teaching base construction, constantly enrich the experimental teaching equipment, based on the students before practice can understand the basic conditions of production practice, the basic talent training of practical skills needed to complete the production of the first line, make the internship units for students to learn to live with, do well on the impression, to eliminate the agreement unit afraid of students affect the normal production, enhance cooperation agreement unit confidence.

\section{E. Teaching practice base is not stable}

Under the condition of market economy, the internship units focus on economic benefit, for the reception of practice teaching of the university students are often not interested in teaching practice is hard to get the support and cooperate with the internship units, difficult is to mobilize the enthusiasm of the internship units, lead to the teaching practice base on to maintain the relationship, and therefore difficult to have stable [4].

\section{Lack of funds for teaching practice base construction.}

"Mutual benefit and mutual benefit" is the road to the construction of teaching practice base. In recent years, due to the school recruitment of students scale expanding rapidly, the school in teaching is able to run the basic premise, the teaching of lodging expenses relative lack in funding, and relatively insufficient funds are more for base construction, and thus discourage the practice unit to the base construction [5].

\section{F. The teaching practice base of each department is unbalanced}

Because of the difference of the subject, the construction of science and engineering teaching practice base is better, and the construction of the teaching practice base of literature, classics and management is more difficult. On the one hand, it is mainly due to the expansion of colleges and universities, the number of students in the school has increased sharply, making the teaching practice base more scarce. On the other hand, the level of emphasis on the construction of the teaching practice base is different from the leadership of the secondary colleges, which leads to the imbalance of the construction of teaching practice base [6].

\section{CONCLUSION}

VI. Students have more practice opportunities to cultivate and train practical skills to improve students' engineering practice and engineering consciousness.

VII. In the talent competition of the 21 st century, science and technology change quickly, applied talents will certainly be a target for numerous companies, and practice base is an important part in training the applied talents. Therefore, the construction of practice base is becoming more and more important to colleges and universities. Only if the practice base is built and well developed, it is possible to develop the talents needed by the society. 


\section{REFERENCES}

[1] Chun Duxiong, Wenguang Zeng,Haiyu Huang, etc. "The practice and understanding of local universities to strengthen teaching practice base construction," Journal of dongguan institute of technology, 2000,pp. 2627.

[2] Xiangbing Meng, Ze Wei,"On the construction of off-campus practice bases in universities," Journal of shenyang normal university (social science edition), 2008,pp. 146-147.

[3] Haiming Yang, Zhiyue Wang, "Discussion on the construction of offcampus practice base in the new era," Journal of yangzhou university (high education research edition). 2007,pp. 88-89.
[4] Aijun Wang, "Research and practice of teaching practice base construction,'Education BBS . Yancheng institute of technology, 2007 pp. 28-29.

[5] Jing Li, Detang Zou, Lung Ninghai,"Research and practice on the reform of agricultural specialty teaching in colleges and universities -taking northeast agricultural university as an example," Journal of education college,September 2011, pp. 72-73.

[6] Jia Tao,"Research on construction and management of teaching practice base of independent college",Science and education BBS,In February, 2016, pp. 13-17. 